\section{Global Environment Facility (GEF)}

Origin. The Global Environment Facility is an independent financial organization that brings together 183 countries in partnership with international institutions, civil society bodies and the private sector to address global environmental issues and support national development initiatives. It was established in 1991 under the aegis of the World Bank, becoming a permanent, separate institution in 1994.

Activities. As of Feb. 2018 the GEF had provided US\$17bn. in grants and co-financed more than 4,000 projects in 170 countries totalling US\$88bn. since 1991. It also serves as the financial mechanism for the Convention on Biological Diversity, the UN Framework Convention on Climate Change, the Stockholm Convention on Persistent Organic Pollutants, the UN Convention to Combat Desertification and the Minamata Convention on Mercury (an agreement to protect human health and the environment from the effects of mercury emissions).

Organization. There is a GEF Assembly comprising representatives of each member country that meets every three to four years. The GEF Council is the main governing body, developing, adopting and evaluating specific programmes. The Secretariat is based in Washington, D.C., and there are also a scientific and technical advisory panel, an evaluation office and a number of agencies managing particular projects.

Headquarters: 1899 Pennsylvania Ave., NW, Washington, D.C., 20006, USA.

Website: http://www.thegef.org

Chief Executive Officer and Chair: Dr Naoko Ishii (Japan).

\section{Greenpeace International}

Origin. Greenpeace evolved out of a series of environmental and anti-nuclear protests in Canada in the late 1960s and early 1970s. In 1985 it became the focus of international attention when agents of the French security services blew up the organization's flagship, Rainbow Warrior, while it was in Auckland Harbour, New Zealand.

Mission. Greenpeace is an independent global environmental organization that aims to secure a planet 'that is ecologically healthy and able to nurture life in all its diversity'. It campaigns to: prevent pollution and abuse of the Earth's land, oceans, air and fresh water; end all nuclear threats; and promote peace, global disarmament and non-violence.

Organization. Greenpeace International has its headquarters in Amsterdam in the Netherlands, from where it co-ordinates worldwide campaigns and monitors and advises national and regional offices in 55 countries.

Financial contributions from governments, political parties and commercial organizations are not accepted. Funding is provided by individual supporters and foundation grants. In 2013 Greenpeace had $3 \mathrm{~m}$. individual supporters.

Headquarters: Ottho Heldringstraat 5, 1066 AZ Amsterdam, Netherlands.

Website: http://www.greenpeace.org

Executive Directors: Bunny McDiarmid (New Zealand) and

Jennifer Morgan (USA).

\section{World Wide Fund for Nature (WWF)}

Origin. WWF was officially formed and registered as a charity on 11 Sept. 1961. The first National Appeal was launched in the United Kingdom on 23 Nov. 1961, shortly followed by the United States and Switzerland.
Mission. WWF has as its mission preserving genetic, species and ecosystem diversity; ensuring that the use of renewable natural resources is sustainable now and in the longer term, for the benefit of all life on Earth; promoting actions to reduce to a minimum pollution and the wasteful exploitation and consumption of resources and energy. WWF's ultimate goal is to stop, and eventually reverse, the accelerating degradation of our planet's natural environment, and to help build a future in which humans live in harmony with nature.

Organization. WWF is the world's largest and most experienced independent conservation organization with over $5 \mathrm{~m}$. supporters (including $1.1 \mathrm{~m}$. in the USA). As at Feb. 2018 there were national offices in 34 countries and territories.

The National Organizations carry out conservation activities in their own countries and contribute technical expertise and funding to WWF's international conservation programme. The Programme Offices implement WWF's fieldwork, advise national and local governments, and raise public understanding of conservation issues.

Address: Rue Mauverney 28, CH-1196 Gland, Switzerland.

Website: http://wwf.panda.org

Director General: Marco Lambertini (Italy).

President Emeritus: HRH The Prince Philip,

Duke of Edinburgh.

President: Pavan Sukhdev (India).

\section{Treaties}

\section{Antarctic Treaty}

Antarctica is an island continent some $15.5 \mathrm{~m}$. sq. $\mathrm{km}$ in area which lies almost entirely within the Antarctic Circle. Its surface is composed of an ice sheet over rock, and it is uninhabited except for research and other workers in the course of duty. It is in general ownerless: for countries with territorial claims, see ARGENTINA; AUSTRALIA: Australian Antarctic Territory; CHILE; FRANCE: Southern and Antarctic Territories; NEW ZEALAND: Ross Dependency; NORWAY: Queen Maud Land; UNITED KINGDOM: British Antarctic Territory.

12 countries which had maintained research stations in Antarctica during International Geophysical Year, 1957-58 (Argentina, Australia, Belgium, Chile, France, Japan, New Zealand, Norway, South Africa, the USSR, the UK and the USA) signed the Antarctic Treaty (Washington Treaty) on 1 Dec. 1959. Austria, Belarus, Brazil, Bulgaria, Canada, China, Colombia, Cuba, Czech Republic, Denmark, Ecuador, Estonia, Finland, Germany, Greece, Guatemala, Hungary, Iceland, India, Italy, Kazakhstan, North Korea, South Korea, Malaysia, Monaco, Mongolia, the Netherlands, Pakistan, Papua New Guinea, Peru, Poland, Portugal, Romania, Slovakia, Spain, Sweden, Switzerland, Turkey, Ukraine, Uruguay and Venezuela subsequently acceded to the Treaty. The Treaty reserves the Antarctic area south of $60^{\circ} \mathrm{S}$. lat. for peaceful purposes, provides for international co-operation in scientific investigation and research, and preserves, for the duration of the Treaty, the status quo with regard to territorial sovereignty, rights and claims. The Treaty entered into force on 23 June 1961. The 53 nations party to the Treaty (29 consultative or voting members and 24 non-consultative parties) meet biennially.

An agreement reached in Madrid in April 1991 and signed by all 39 parties in Oct. imposes a ban on mineral exploitation in Antarctica for 50 years, at the end of which any one of the 29 voting parties may request a review conference. After this the 